\title{
New Requirements of the Basel Committeee on Banking Supervision to Capital as a Measure to Ensure the Stability of the Banking Sector
}

\author{
Valitov S.M. \\ Nigmetzyanov A.A.
}

Kazan Federal University, Institute of Management, Economics and Finance, Kazan, 420008, Russia

\section{Doi:10.5901/mjss.2014.v5n24p294}

\begin{abstract}
In this paper is devoted to problems of the introduction of new capital and liquidity standards proposed by Basel III. In particular, the authors critically analyze the lack of rigidity of the new requirements especially with respect to systemically important financial institutions. They also emphasize the necessity of macroprudential regulation to build more resilient financial system.
\end{abstract}

Keywords: systemically important financial institute, systemic risk, financial crisis, micro-prudential regulation, macro-prudential regulation, bank capital, liquidity, liquidity coverage, net stable funding.

\section{Introduction}

'In the absence of detailed, prescriptive global standards, national regulators enjoy considerable discretion with regard to their local approaches. In practice, such flexibility means any one country's efforts to deal with the problem can potentially be undercut by another country's inaction' [1]. For this reason, in 1974, the Basel Committee on Banking Supervision (BCBS) was established by the Group of 10 (G-10) with the aim of preventing financial crises of international scale [2][3]. In 1988, Basel I proposed international standards for capital requirements. However, only narrow spectrum credit risk standards were not enough to prevent a series of crises in the nineties, for instance, the Mexican and the Asian [4]. Later, in 2004, Basel II was adopted, which consisted of three pillars: capital, supervisory review process and market discipline. However, even during Basel II project development, Half criticized the insufficiency of attention given to the regulation of 'financial conglomerates' [5].

\section{Shortcomings of Basel II}

The last global financial crisis, exposed shortcomings of Basel II and forced BCBS [6] to soundly revise existing capital adequacy requirements, diversification of credit portfolio, standards of liquidity management, and other spheres of bank activities to mitigate systemic risk [7]. It was revealed that Basel II standards were inadequate to prevent or at least to reduce the effects of global financial turmoil [8]. For instance, Northern Rock's internal risk model for residential mortgages in 2007 was in compliance with Basel II standards [9]. As a result, BCBS has developed a new edition of the provisions, so-called Basel III. It aimed to eliminate shortcomings of the Basel II, strengthen stability of the global financial system and prevent the onset of a new global financial crisis. Primarily Basel III changed conception from microprudential regulation, which was used by Basel II [10], to macro-prudential. In other words, the main concern of the new Accord is to protect not single bank, but the whole banking system. Moreover, Brunnermeier et.al argued that Basel II standards provoked banks to become 'too big', because in that case banks could count on government support in stress situation [11]. However, Basel III does not cancel Basel II [12], but modernize it and have an aim to adequately address the following shortcomings [13][14][15][16]: incentives for 'too big to fail'; high level of systemic risk; lack of macroprudential regulation; lack of international coordination; lack of transparency; treatment of pro-cyclicality. Trying to solve these issues, Basel III Accord [17] becomes one of the most important international regulatory responses to 'too big to fail' problem [18]. New Accord demands higher requirements to capital and liquidity, particularly to SIFIs. 


\section{Requirements to the Structure and Quality of Bank Capital}

The requirements to the structure and quality of the bank capital base have been tightened by Basel III agreement [19]. The Basel Committee proposed 'to strengthen global capital and liquidity regulations with the goal of promoting a more resilient banking sector' [17]. New capital requirements are introduced for the tier 1 and tier 2 capitals. Hybrid and quasi debt instruments are gradually withdrawn [14]. A list of allowed deductions from the capital base is being defined. Requirements to the own bank capital and capital of the first generation are being increased. Thus, Basel III focuses on the function of the equity instruments to absorb losses, what can be explained by the nature of the recent crisis [20]. Related to SIFIs, BIS [21] proposed 'higher loss absorbency requirement' from $1 \%$ to $2.5 \%$ depending on the systemic importance of the organization. This extra loss absorbency will come from tier 1 capital. However, this requirement will be introduced not earlier than 2019. Therefore, Basel III defines two levels of capital: tier 1 capital as a capital which can absorb losses during the current bank activity, 'going concern', and tier 2 capital as a capital which is able to cover the losses in the course of the termination of bank activity, 'gone concern' [22][23]. The tier 1 capital consists of Common Equity Tier 1 capital, which is the most reliable part of the capital; and Additional Tier 1 capital [24]. Common Equity Tier 1 capital includes the ordinary shares and share premium on ordinary shares. For Additional Tier 1 capital the Basel Committee proposed to include non-cumulative perpetual privileged stocks. In contrast, innovative hybrid instruments, such as subordinated loans with additional conditions, will be gradually excluded from the composition of the capital base of banks [25]. Tier 2 capital includes preferred stock with non-perpetual and debt-like features and subordinated debt [26]. Tier 3 capital, according to Basel III, is being abolished by the new system [27]. In the Basel I and the Basel II, deductions were carried out of both tier 1 and tier 2 capitals. In contrast, in accordance with Basel III, the main burden falls on the basic capital of tier 1 capital. Although, the consultation document does not directly set the ratio of tier 1 and tier 2 capitals, it proposes, to establish the ratio through minimum capital adequacy requirements for coverage for expenses [24].

Furthermore, the consultative document provides creating of two buffers; capital conservation, to cover banking losses during economic downturn, and counter-cyclical, to limit excessive bank credit activity [28][29]. The main purpose of formation of these buffers is to maintain a capital reserves and ability to absorb additional losses. The sense of these innovations can be explained, that during the onset of the last financial crisis some banks used to distribute dividends and personnel bonuses [30]. Moreover, the recent financial and economic crisis has shown the dependence of credit risk assessment on the phase of the economic cycle. In other words, in periods of economic recovery the risk for the banks are low, as well as for capital requirements. This means that banks will be able to increase lending, which will serve as a source of new pro-cyclical momentum [31][32]. As a result of these approaches, banks sharply reduced creating volumes of lending in the period of economic decline, when the economy was in the greatest need for additional capital. Therefore, the introduction of counter-cyclical buffer, determined by the ratio of the total value of credits and GDP [33], aimed to solve this problem by curbing the credit activity of the banks in periods of economic recovery and promoting in periods of recession [34]. Exceeding the threshold values of the record identified by the national regulator is the signal for the establishment of bank counter-cyclical buffer. In turn, conservation buffer is introduced for stability, with respect to both individual and systemic risks. The aim of this action is to support the banks during periods of 'systemic' problems. Practically, it is a system of banking insurance of protection from 'contagion risk'. In other words, this is a risk arising in the case, when the adverse process in one country lead to the fall of the rating or credit crunch in other countries too. Particularly, this requirement is important to prevent risks imposed by 'too interconnected' financial institutions, one of the characteristics of the SIFIs. In the case of forming by banks both counter-cyclical and cyclical, requirements will increase in two times up to 9,5\% assets risk-weighted, since added another 2,5\% in the form of the counter-cyclical buffer [24]. In turn, to improve the quality of capital and prevent excessive leverage in the banking sector, the Basel Committee has worked out proposals for the introduction of a new regulatory indicator 'leverage ratio' [24]. That is the ratio of capital to total volume of its assets and off-balance claims, not weighted by risk level.

Supporting new requirements, Hilderband [35] states that higher leverage or lower leverage ratio, the lower opportunity to absorb losses. As a result, the resilience of this bank to stress is lower. Similarly, Lui [36] highlights the importance of leverage ratio and capital requirements to sustain stability especially of large banks, because they can be characterized as 'too big to be regulated'. For instance, Australian banks, having higher level of liquidity and leverage ratio in comparison with UK banks, better resisted to the last financial debacle [36]. Hence, in addition to the new requirements to capital structure, the Basel Committee regulates the overall structure of the banks' balance by way of determination of the percentage of the borrowed funds. However, Petersen et al. [37] criticize the way of calculation of the leverage ratio and went further to argue that the new methodology of leverage ratio estimation does not improve this standard in comparison with Basel II. Thus, this instrument alone will not be able predict and prevent systemic risk, 
especially imposed by large financial institutions [37]. Moreover, Kashyap et al. [38] predict that introduction of this factor may significantly increase the cost of all bank credits, because this factor is not entered on the weighted risk, but on the gross value of assets, that would be more targeted on risk reduction.

Nevertheless, BCBS chose the option with the lowest incremental load to SIFIs. While many large banks, particularly in the USA, have already complied requirement of 10 percentage of capital. In contrast, European banks, as a result of the imposed changes, will be forced to significantly clean its capital base, excluding deferred tax and share of participation of subsidiaries with a one-time increase in the number of common shares and retained earnings, having the aim to restore the capital base. However, in spite of progressiveness of the idea of extra charge for SIFIs, Petitjean notes two issues to implement new requirements [16]. First of all, it does not exist elaborated mechanism of identifying systemic risk urgently to impose proper surcharge timely. Secondly, as Duffy [39] described, according to the US regulation banks have already had to issue new shares in stress situation. Thus, despite the presence of updated act, but in the absence of the coercion mechanism, reforms may be will not be implemented.

\section{Standards for Liquidity Management}

The last financial crisis started as a liquidity crisis [18]. However, till date there are not much of internationally agreed standards. Taking into account these facts, the Basel III proposed standards for liquidity management [40]. Thus, the Basel Committee has introduced two minimum standards for liquidity: the Liquidity Coverage Ratio (LCR) and the Net Stable Funding Ratio (NSFR) [25], which should be external indicators of sustainability of the banks in case of the crisis of liquidity [24]. Like the international capital standards liquidity standards will establish the minimum requirements and will maintain equal conditions on the international level.

\subsection{The liquidity coverage ratio (LCR)}

LCR allows assessing the bank capacity to continue its activities within 30 days of the stress [25], and defined as the ratio of liquid assets to net cash outflow. Liquid assets are divided into two levels. The first one includes cash, bank reserves and debt obligations of public entities, in other words, assets with 100\% guarantee, which should be liquid in times of stress. These assets cannot be cut under the stress. The second level assets include securities issued by non-financial institutions. Unlike Level 1 assets, the size does not exceed 40 percent of the total of liquid assets, and 15 percent discount is applied to them. Although, a purpose of BCBS in determining the level of liquidity is the estimation of this level at the actual moment and, theoretically, the wording of the Basel Accord means determining of this level ex-ante, following the recommendations of the Committee estimation is obtained ex-post [41]. Thus, practically, evaluation of the level of liquidity is based on the data of the previous period.

\subsection{Net stable funding ratio}

NSFR enables the assessment of liquidity within a one year time period. This indicator is intended to increase elasticity on a long term by creating additional incentives for banks to finance their activity from more stable sources on an ongoing structural basis [42]. In other words, it is assumed, that it will be able to protect banks involved in long term lending business based on wholesale market. For instance, it was suggested, that the proper NSFR would be able to prevent failure of the UK's Northern Rock, which used to be one of the top banks in mortgage business [43]. NSFR is defined as the ratio of available stable funding sources to the required volume of stable funding; and should be above $100 \%$. NSFR is aimed at limiting the excessive dependence on major sources of finance in the periods of excess liquidity in the market and contributes to a more accurate assessment of risk liquidity on all balance and off-balance items. This approach will help to minimize the possible sharp deterioration of liquidity and prevent banks from establishment of liquid assets with short-term funding sources, which become mature immediately after the established, by supervisory body, legal period. In turn, stable funding can be both own equity and borrowed funds, which are a reliable source of financing during the year of the stress. Lopez-Espinosa et.al [44] empirically proves the necessity of NSFR proposed by Basel Committee to reduce systemic risk. However, theoretically having positive goals, Pengelly [43] indicates practical difficulties that await banks to comply with new Basel III requirements relatively NSFR. Namely, European banks will have to release long-term liabilities on 2.7 trillion euro. This task is complicated by the bail-in regime, or imposition of losses on bondholders. Simplifying, banks will have to sell bonds at a high price to a small group of investors. Taking into account, the huge necessity of capitalization for the systemically important banks, it seems that this task, of finding buyers in undercapitalized market [45] till 2018, will be significantly complicated for SIFIs. 


\section{Problems Unresolved by Basel III}

Thus, practically, the introduction of minimum capital adequacy and liquidity requirements is not without problems, particularly in the EU Member States. 'There is a potential for differences in how the rules are transposed in each of the EU countries' [46]. Predictably, that implementing of the Basel III is taking longer than anticipated due to complicated constitutional structure of the EU [46]. Nevertheless, the USA is not swift too due to debates on the capital definitions [46]. In contrast, Switzerland identified systemically important institutions and surcharged higher standards in the "too big to fail' framework [46]. Although the common goal of members of the Basel Committee is to strengthen financial stability, there are different views on issue of establishing of higher capital requirements both quantitatively and qualitatively. For instance, Admati et al. suggest that introduction of higher requirements will strengthen the financial stability [47]. Similarly, King [48] states that leverage ratio and capital requirements are essential for banks viability and, although these requirements do not guarantee 100 percent surveillance, anyway, they will allow bank to fail without systemic consequences. In contrast, DeAngelo and Stulz [49] argue that high leverage is optimal for banks, explaining it by constant increasing of leverage over the last 150 years and that high leverage is the intrinsic characteristic of profitability of the banking business. Moreover, they underlines that this rule does not make exception for 'too big to fail' institutions. Likewise, Kashyap et al. contend that higher requirements are not economically justified, because it will increase the cost of funds [38]. Similarly, Hanson et al. [50] maintain that imposition of higher requirements on banking sector will shift the banking activity to unregulated shadow-banking sector. For instance, the last financial crisis, as Metric [51] notes, started from shadow banks. For this reason, they should be regulated similarly to banks. Otherwise, the systemic risk will only increase. As a result, following these types of critics in 2013 the Basel Committee [52][53][54] decreased its requirements to liquidity provisions by lowering the run-off rates of deposits, corporate liquidity facilities and interbank liquidity facilities. However, the UK, Sweden, Spain, with the European Central Bank, support the stricter requirements to the quantitative and qualitative characteristics of capital. In contrast, Germany and France, interested in maintaining of some of the components of the banking capital as highly liquid, and with European Commission support, have the opposite point of view [55].

Thus, on the one hand, Basel III proposals can constrain banks' capitalization, on the other hand, they build a more stable financial system. Nevertheless, minimal requirements to the capital size established by the Basel III are more appropriate than the previous ones. Moreover, they are not sufficiently stringent [56][57]. In other words, the capital requirements recorded in Basel III are insufficient to prevent from possible crises. For instance, according to Hanson et al. estimations, this figure should be at the level of 15\% [58]. Moreover, Miles [59] calculated that the proper standard of bank capital should be about 20\%. Admati and Hellwig argue, that 'increasing equity requirements from 3 percent to 25 percent of banks' total assets would involve only a reshuffling of financial claims in the economy to create a better and safer financial system [60].' Meanwhile, the possibility of easing of requirements to the quality of bank capital will not limit possible losses, which can become taxpayers' burden. In contrast, opponents of the establishment of higher standards claim that this will significantly increase fund costs, reduce the volume of lending and slow the rate of economic growth in general [38]. However, calculations provided by independent scholars prove the necessity of new standards at the international level and higher requirements for systemically important financial institutions.

\section{Conclusion}

Conclusively, despite positive changes in the process of reforming the supervision and regulation, a critical issue of capital requirement in respect of 'too big to fail' remains unresolved. The larger the size of the 'too big to fail' financial institution, the more acute the need for rigorous standards of control will be. Thus, countries which have 'too big to fail' financial institutions to avoid repeating of the last financial debacle events, when the cost of support and liquidation of financial 'leviathans' were transformed to taxpayers, have to elaborate and introduce more stringent rules and international standards of macro-prudential regulation. This policy will be more consistent with aims stated by the USA and European governments.

\section{References}

Brummer Ch., Soft Law and the Global Financial System: Rule Making in the 21st Century (Cambridge University Press 2012), p.250

Basel Committee on Banking Supervision, History of the Basel Committee and its Membership (2009) Bank for International Settlements $<\mathrm{http}: / /$ www.bis.org/bcbs/history.pdf>

Cassis Y., Crises and Opportunities: The Shaping of Modern Finance (Oxford University Press 2011), p.124 
Bath J.R., Caprio G., Levine R.Jr., Rethinking Bank Regulation: Till Angels Govern (Cambridge University Press 2006), p.66

Half C., 'Evolving Trends in the Supervision of Financial Conglomerates: A comparative Investigation of the Responses to Challenges of Cross-Sectoral Supervision in the United States, European Union, and the United Kingdom' (30 April 2002) Harvard Law School, International Finance Seminar, 21

Basel Committee on Banking Supervision, Enhancements to the Basel II framework - final version (July 2009) Bank for International Settlements <http://www.bis.org/publ/bcbs157>

Schwerter S., 'Basel III's ability to mitigate systemic risk' (2011) Journal of Financial Regulation and Compliance 337 $<$ <ttp://www.financialstabilityboard.org.>

Foot M., 'Can Macro-prudential Regulation Reduce Financial Instability?'(2012)80 The Manchester School 1-20, 9

A.Lehar, 'Measuring systemic risk: a risk management approach' (2005) 29(10) Journal of Banking and Finance 2577

Brunnermeier M., Crocket A., Goodhart C., Persaud A.D., Shin H., 'The fundamental principles of financial regulation' (2009) Geneva Reports on the World Economy 11, ICMB and CEPR, Geneva and London

Basel Committee on Banking Supervision, Bank for International Settlements, Basel II: International convergence of capital measurement and capital standards: A Revised Framework (2005) <http://www.bis.org/publ/bcbsc111.pdf>

Hellwing M.F., 'Systemic risk in the financial sector: an analysis of the subprime-mortgage financial crisis'(2009) 157(2) De Economist 129-207

Bondarchuk P.K., Totimyanina K.M., 'From Basel II to Basel III'(May 2012) 5 Leazing LRS 'Garant'

Borio C., 'Towards a macroprudential framework for financial supervision and regulation?'(2003) BIS Working Paper No 128, Bank for international settlements, Basle

Petitjean M., 'Bank failures and regulation: a critical review' (2013) 21(1) Journal of Financial Regulation and Compliance 16-38

Basel Committee on Banking Supervision, Consultative Document, Strengthening the Resilience of the Banking Sector (December 2009) Bank for International Settlements <http://www.bis.org/publ/bcbs164pdf

King P., Tarbert H., 'Basel III: An Overiew' (May 2011) 30(5) Banking and Financial Services Policy Report 1-18, 9

Basel Committee on Banking Supervision, Basel III: A Global Regulatory Framework for more Resilient Banks and Banking Systems (2010) Bank for International Settlements <http://www.bis.org/publ/bcbs189.pdf>

Monroe M.F., 'Basel III redefines capital' (2010) ABA Banking Journal 33

Basel Committee on Banking Supervision, 'Global systemically important banks: updated assessment methodology and the higher loss absorbency requirement' (July 2013) Bank for International Settlements <http://www.bis.org/publ/bcbs255.htm>

Financial Stability Institute, Basel III Tutorial 13 (2011) <http://www.fsiconnect.org//ms/content/imported_5214/lo_3898/menu.html>

Dermine J., 'Bank Regulations after the Global Financial Crisis: Good Intentions and Unintended Evil' (09/2013) 19(4) European Financial Management 658

Basel Committee on Banking Supervision, Basel III: A global regulatory framework for more resilient banks and banking systems-revised version June 2011 (June 2011) Bank for International Settlements <http://www.bis.org/publ/bcbs189htm>

Financial Stability Institute, Basel III Tutorial 4 (2011) <http://www.fsiconnect.org//ms/content/imported_5214//0_3898/menu.html.>

Financial Stability Institute, Basel III Tutorial 11 (2011) <http://www.fsiconnect.org//ms/content/imported_5214/lo_3898/menu.html.>

Basel Committee on Banking Supervision, Basel II: International Convergence of Capital Measurement and Capital Standards: a Revised Framework (June 2006) Bank for International Settlements <http://www.bis.org/publ/bcbs128.htm>

Basel Committee on Banking Supervision, Final elements of the reforms to raise the quality of regulatory capital issued by the Basel Committee (13 January 2011) Bank for International Settlements <http://www.bis.org/press/p110113.htm>

Basel Committee issues final elements of the reforms to raise the quality of regulatory capital (last update: 7 August 2013) $<$ http://www.istein.org>Dnews>

Caruana J., General Manager, Bank for International Settlements, Speech at the 13th Annual International Bank Conference: The Challenge Of Taking Macroprudential Decisions: Who Will Press Which Button(s)? (Sept. 24, 2010) 3 < http://www.bis.org Ispeeches/sp100928.pdf.>

Basel Committee on Banking Supervision, Results of the comprehensive quantitative impact study (December 2010) Bank for International Settlements <http://www.bis.org/publ/bcbs186.pdf>

Basel Committee on Banking Supervision, Joint Quantitative Impact Study (last update 17 July 2013) Bank for International Settlements $<$ http://www.bis.org/bcbs/qis/>

Basel Committee on Banking Supervision, Guidance for national authorities operating the countercyclical capital buffer (December 2010) Bank for International Settlements <http://www.bis.org/publ/bcbs187.htm>

Wellink N., Chairman, Basel Committee of Banking Supervision, Remarks at the 16th International Conference of Banking Supervisors: A New Regulatory Landscape (Sept. 22,2010)4 <http://www.bis.org/review/r101124b.pdf.>

Hilderbrand P.M., 'Is the Basel II Enough? The Benefits of the Leverage Ratio' (2008) Markets Group Lecture, London School of Economics, London <http://www.bis.org/review/r081216d.htm>

Lui A., 'Macro and Micro Prudential Regulatory Failures Amongst Financial Institutions in the United Kingdom: Lessons from Australia' (November 28, 2010) Finance and Corporate Governance Conference 2011 Paper, Social Science Research Network $<$ http://www.papers.ssrn.com/sol3/papers.cfm?...>

Peterson M.A., Maruping J.B., Mukuddem-Petersen J., Hlatshwayo LNP., 'A Basel perspective on bank leverage' (22 July 2013) 23(17) Applied Financial Economics 1361-1369

Kashyap A.K., Stein J.C., Hanson S., 'An analysis of the Impact of 'Substantially Heightened' Capital Requirements on Large Financial 
Institutions' (May 2010) Harvard University mimeo

Duffie D., 'How big banks fail and what to do about it' (Princeton University Press 2011)

Wellink N., 'The new framework for banking supervision' (January 2011) FSI High Level Meeting on 'The Emerging Framework to Strengthen Banking Regulation and Financial Stability' for Africa

Balasubramanyan L., VanHoose D.D., 'Bank balance sheet dynamics under a regulatory liguidity-coverage-ratio constraint' (September 2013) 37 Journal of Macroeconomics 53

Gideon F., Peterson M.A., J.Mukuddem-Peterson J., Hlatshwayo LNP., 'Basel III and Net Stable Funding Ratio' (2013) 2013 Applied Mathematics

Pengelly M., 'The funding squeeze' (December 2012) 25(4) Risk 40

Lopez-Espinosa G., Moreno A., Rubia A., Valderamma L., 'Short-term wholesale funding and systemic risk: a global CoVar approach' (2012) 36(12) Journal of Banking and Finance 3150-3162

Acharia V.V., Pederson L.H., Philippon, Richardson M., 'Measuring Systemic Risk' (2010) Working Paper 10-02 Federal Reserve Bank of Cleveland

Cooper J., 'Report: International banking operations-Regulation-The regulatory challenge for cross-border banking' (March 2013) The Banker 1

Admati A.R., DeMarzo P.M., Helling M.F., Pfleiderer P., 'Fallacies, Irrelevant Facts, and Myths in the Discussion of Capital Regulation: Why Bank Equity Is not Expensive' (September 2010) Stanford GSB Research Paper No.2063

King M., Governor of the Bank of England, Speech at the Lord Mayor's Banquet for Bankers and Merchants of the City of London at the Mansion House (2012) <http://www.bankofengland.co.uk/publications/Documents/speeches/2012/speech587.pdf>

DeAngelo H., Stulz R.M., 'Why Leverage is Optimal for Banks' (June 2013) National Bureau of Economic Research, Working Paper 19139, NBER Working Paper Series

Hanson S.G., Kashyap A., Stein J.C., 'A macroprudential approach to financial regulation' (2011)25 Journal of Economic Perspective 3

Metric A., 'The Banks' New Clothes: What's Wrong with Banking and What to Do about It' (March 2013) 50(1) Finance and Development 54

Basel Committee on Banking Supervision, Basel III: the Liquidity Coverage Ratio and Liquidity Risk Monitoring Tools (2013) Bank for International Settlements <http://www.bis.org/publ/bcbs238htm>

Basel Committee on Banking Supervision, Consultative Document, Liquidity coverage ratio disclosure standards (19 July 2013) $<$ http:www.bis.org/publ/bcbs259.pdf>

Kowalik M., 'Basel Liquidity Regulation: Was It Improved with the 2013 Revisions?' (2013) Federal Reserve Bank of Kansas City, Economic Review 65

Комарова К., Базель III: реформа капитала (Июнь 2012)6, БДМ. Банки и деловой мир

Mintz S.L., 'Five Questions: Anat Admati Says More Bank Equity Is Needed', Institutional Investor (April 2012)

Stiglitz J., 'The Lessons Of The North Atlantic Crisis For Economic Theory And Policy', Guardian (10.05.2013)

Hanson S.G., Kashyap A., Stein J.C., 'A macroprudential approach to financial regulation' (2010) Working Paper No.10-29, The University of Chicago, Booth School of Business, Chicago, IL.

Miles D., 'What is the Optimal Leverage for a Bank?' (27 April 2011) Vox.EU.org <http://www.voxeu.org/>

Admati A., Hellwig M., The Bankers' New Clothes (Princeton University Press. Princeton, NJ 2013), p.191 